IRA-International Journal of Education \& Multidisciplinary Studies

ISSN 2455-2526; Vol.03, Issue 03 (2016)

Institute of Research Advances

http://research-advances.org/index.php/IJEMS

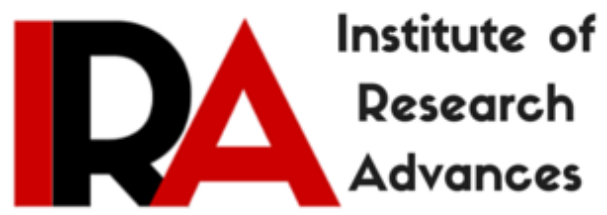

\title{
Impact of Attitudes and Facilities in Effective Implementation of Guidance and Counselling Programmes in Selected Institutes of Technology in Nyanza Province, Kenya
}

\author{
${ }^{1}$ Esther Okenyuri Nyaundi Nyarangi \& ${ }^{2}$ Makworo Edwin Obwoge \\ 1,2 KISII University \\ P.O. Box 408-40200, KISII, Kenya.
}

DOI: http://dx.doi.org/10.21013/jems.v3.n3.p10

\section{How to cite this paper:}

Nyaundi Nyarangi, E., \& Edwin Obwoge, M. (2015). Impact of Attitudes and Facilities in Effective Implementation of Guidance and Counselling Programmes in Selected Institutes of Technology in Nyanza Province, Kenya. IRA International Journal of Education and Multidisciplinary Studies (ISSN 2455-2526), 3(3).

doi:http://dx.doi.org/10.21013/jems.v3.n3.p10

(C) Institute of Research Advances

(c)) EY-NC

This works is licensed under a Creative Commons Attribution-Non Commercial 4.0 International License subject to proper citation to the publication source of the work.

Disclaimer: The scholarly papers as reviewed and published by the Institute of Research Advances (IRA) are the views and opinions of their respective authors and are not the views or opinions of the IRA. The IRA disclaims of any harm or loss caused due to the published content to any party. 


\begin{abstract}
Education systems in the world today are acting as the main agents for social change. Learners attending this systems are always away from their parents and other elderly people who would help them cope with challenges they face. This has necessitated inclusion of guidance and counselling department services in most institutions. In Kenya the government introduced this in all learning institutions. Even with this, students studying in Institutes of Technology in Nyanza province in Kenya display a host of problems ranging from poor academic performance to low self-esteem, which drive them to open drunkenness, skipping of classes, stealing other people's property, sexual misconduct and actual or attempted suicide. The problems exist despite the fact that guidance and counselling programmes are in place in these institutions. The purpose of this study therefore was to establish the impact of attitudes and facilities in effective implementation of guidance and counselling programmes in the Technical and Vocational Education Training (TVET) institutions in Nyanza province. The study employed the descriptive survey research design. It was carried out in Moi Institute of Technology (MIT) and Gusii Institute of Technology (GIT). The target population constituted of principals, the teacher counsellors and the students of the two institutions. Each institution had two teacher counsellors. MIT had 600 students and GIT had 1800 students making a total of 2400. The sample size was made of 2 principals, 4 teacher counsellors and 240 students. Purposive sampling was used to select the principals and the teacher counsellors. Stratified random sampling and simple random sampling were used to select the student's sample. Data was collected using questionnaires and it was analyzed using descriptive statistics. The results of the study indicated that the major challenge facing effective implementation of guidance and counselling programs in the Institutes of Technology (ITs) was lack of sufficient facilities due to poor support by the principals and Board of Governors (BOG). The researcher therefore recommends that there is need for all principals of ITs in Nyanza to be taken through a thorough and informative training on the importance of giving full support to guidance and counselling programs in their institutions. There is also need to work towards changing the negative attitude towards guidance and counselling held by some students.
\end{abstract}

Key Words: Guidance and counselling, Technical and Vocational Education Training, Attitudes, Facilities.

\title{
INTRODUCTION
}

The concept of Guidance and Counselling is as old as man. It is man's heritage from the past. The earliest occasion in which humans sought a counsellor, was when Adam reaped the consequences of his eating the apple in the Garden of Eden (Gibson and Mitchell, 2008). Gibson and Mitchell (2008), continue to say that no proof exists of this early beginning to counselling, but an abundance of evidence suggests that persons through-out the ages have sought the advice of others believed to possess superior knowledge, insights or experience. Perhaps the first counterparts of the present day counselor were the chieftains and elders to whom the youths turned or were sent to for advice and guidance. In early civilizations, the philosophers, priests and other representatives of gods and religions assumed the role of advisors and counselors.

As time passed, society, the United States in particular, was growing more complex and finding one's appropriate place in it and adjusting to it were becoming increasingly more 
complicated. Many adults were turning to such traditional sources of counselling as their family physician, the minister or the employer. As a result, the 20th century seemed ripe for a considered and genuinely scientific approach to meeting many human needs. The time had come for the development of counselling and many psychological oriented programmes to meet these needs (Gibson \& Mitchell, 2008).

According to Pope and $\mathrm{Hu}$ (2002), counselling, particularly career guidance and counselling started becoming a thing of great interest to psychologists, educators and administrators in the People $\mathrm{ee}$ Republic of China in the 1990's when there were massive government lay-offs from jobs whenever an enterprise was not profitable. For many Chinese, especially those over 30 years old, this was the first time they had to think about what they were going to do with their lives and their careers. People who were accustomed to obeying authority and allowing authority to manage their lives now required new sources of guidance for their future and strategies to cope with the new order.

Kinara (2002), says that the concept of guidance and counselling is not a new one in Kenya; the traditional community practiced a form of it. Narayana (2002) observes that in the traditional setting, people sought solace and comfort to their problems from family members and close associates. Due to this attitude and easy lifestyle of those days, no individual suffered undue stress. However, Kenya has undergone rapid social, cultural and technological change since independence. Improved health-care has led to a rise in population and expansion in education which have enabled many Kenyans to be enlightened. This change has brought about urbanization which has also caused ruralurban migration. The rural-urban migration has resulted in progressive breakdown of the traditional large family set ups in favour of nuclear ones (ROK, 1979). This development has therefore interfered with the traditional machinery of offering guidance and counselling. Grandparents who offered the services have been left behind and parents find themselves in towns alone with their children. The parents cannot effectively offer the critically needed developmental guidance that the youths require because of their busy working schedules or because tradition forbids them to tread on certain "taboo" topics. Young people therefore have grown up without crucial guidance and counselling (Migiro, 2005).

The government of Kenya has tried to fill up this gap by introducing guidance and counselling in all educational institutions with the hope that it will fill up the part traditionally played by grandparents. It was also hoped that this would help students to be equipped with life skills which would enable them to handle their problems in an informed and mature manner in order to curb their wanton destruction. However, the problem of student discipline still exists.

Technical education institutions in Kenya, like all other normal educational institutions, have a serious problem of student riots which cause immense destruction of property and loss of human lives. Masinde (2003) in a study of one TVET Institution in Kenya states that students in these institutions have a host of emotional and psychological problems for which they need support in order to enable them go through college life. According to Nugent and Jones (2005), the demand for counselling services for people with normal developmental concerns continues to grow and spread in schools, colleges and communities. 


\section{OBJECTIVES}

The study was guided by the following objectives;

(i) To determine whether there are well established guidance and counselling facilities in Institutes of Technology in Nyanza province.

(ii) To establish the attitude of principals and students towards guidance and counselling at Institutes of Technology in Nyanza province.

\section{METHODOLOGY}

The study employed the descriptive survey research design. It was carried out in Moi Institute of Technology (MIT) and Gusii Institute of Technology (GIT). The target population constituted of principals, the teacher counsellors and the students of the two institutions. Each institution had two teacher counsellors. MIT had 600 students and GIT had 1800 students making a total of 2400. The sample size was made of 2 principals, 4 teacher counsellors and 240 students. Purposive sampling was used to select the principals and the teacher counsellors. Stratified random sampling and simple random sampling were used to select the student"s sample. Data was collected using questionnaires and it was analyzed using descriptive statistics.

\section{RESULTS AND DISCUSSION}

\section{Guidance and Counselling Establishment}

In order to find out whether there was a well established guidance and counselling department in TVET institutions, a sample of 2 principals, 4 teacher counsellors and 240 students were asked to respond to a question on whether they had a well established guidance and counselling department in their institutions and then further asked to assess the status of the facilities of that department. The analysis of the results is summarized in table 1 and 2.

Table 1: Establishment of Guidance and Counselling Department.

\begin{tabular}{lccccc}
\hline \hline Respondent & \multicolumn{3}{c}{ Response } \\
\hline \hline & \multicolumn{2}{c}{ Yes } & & \multicolumn{2}{c}{ No } \\
\cline { 2 - 3 } \cline { 5 - 6 } \cline { 5 - 6 } \cline { 5 - 6 } Frequency & Percentage & & Frequency & Percentage \\
Principals & & $(\%)$ & & $(\%)$ \\
Teacher counsellors & 3 & 100 & & & 0 \\
Students & 137 & 75 & & 1 & 25 \\
\hline \hline Total & 142 & 57 & & 103 & 43 \\
\hline \hline
\end{tabular}

The analysis shows that $100 \%$ of the principals agreed that there was a well established guidance and counselling department while $75 \%$ of the teachers and $57 \%$ of the students 
were in agreement with this. Twenty five percent $(25 \%)$ of the teacher counsellors and $43 \%$ of the students said that the department was not well established. On average a higher percentage of the respondents $(57.7 \%)$ were in agreement that there was a well established guidance and counselling department in the Institutes of Technology.

Table 2: Adequacy of Facilities in the Guidance and Counselling Departments

\begin{tabular}{|c|c|c|c|c|c|c|c|}
\hline Item & Respondent & & & & Response & & \\
\hline & & Freq.. & $\begin{array}{l}\text { Adequate } \\
(\%)\end{array}$ & Freq. & $\begin{array}{l}\text { Inadequate } \\
(\%)\end{array}$ & Freq. & $\begin{array}{l}\text { No response } \\
\text { (\%) }\end{array}$ \\
\hline Office & Principal & 2 & 100 & 0 & 0 & 0 & 0 \\
\hline & Counsellor & 0 & 0 & 2 & 50 & 2 & 50 \\
\hline & Student & 95 & 39.6 & 102 & 42.5 & 43 & 17.9 \\
\hline Average (\%) & & & 46.5 & & 30.8 & & 22.6 \\
\hline Reference & Principal & 0 & 0 & 2 & 100 & 0 & 0 \\
\hline books & Counsellor & 1 & 25 & 3 & 75 & 0 & 0 \\
\hline & Student & 65 & 27 & 116 & 48.3 & 59 & 24.6 \\
\hline Average (\%) & & & 17.3 & & 74.4 & & 8.2 \\
\hline Charts & Principal & 0 & 0 & 2 & 100 & 0 & 0 \\
\hline & Counsellor & 0 & 0 & 2 & 50 & 2 & 50 \\
\hline & Student & 28 & 11.6 & 135 & 56.25 & 77 & 32.1 \\
\hline Average (\%) & & & 3.7 & & 68.8 & & 27.4 \\
\hline Radio & Principal & 0 & 0 & 2 & 100 & 0 & 0 \\
\hline & Counsellor & 0 & 0 & 2 & 50 & 2 & 50 \\
\hline & Student & 48 & 20 & 124 & 51.7 & 68 & 28.3 \\
\hline Average $(\%)$ & & & 6.7 & & 67.3 & & 26 \\
\hline Video & Principal & 0 & 0 & 2 & 100 & 0 & 0 \\
\hline & Counsellor & 0 & 0 & 2 & 50 & 2 & 50 \\
\hline & Student & 103 & 42.9 & 69 & 28.75 & 68 & 28.3 \\
\hline Average (\%) & & & 14.3 & & 59.7 & & 26 \\
\hline Seminars & Principal & 0 & 0 & 2 & 100 & 0 & 0 \\
\hline & Counsellor & 1 & 25 & 0 & 0 & 3 & 75 \\
\hline & Student & 38 & 15.8 & 132 & 55 & 70 & 29.2 \\
\hline Average (\%) & & & 13.7 & & 51.7 & & 34.6 \\
\hline
\end{tabular}

The analysis in table 2 shows that on average, the office (45.6\%) was the only adequate facility since it was mentioned by a higher percentage while reference books $(74.4 \%)$, charts $(68.8 \%)$, radio $(67.3 \%$, video $(59.7 \%)$ and seminars $(51.7 \%)$ all were inadequate. 
The overall picture shows that most facilities were not adequate in the guidance and counselling department.

There was a low response (57.7\%) on the establishment of the guidance and counselling facilities in Institutes of Technology in Nyanza Province. This tends to show that there was still need to upgrade the facilities. As indicated by table 2, it was apparent that the administration of the various institutes have provided space in terms of office space for the teacher counsellors and also tried to get resource people to speak to the students. This was not sufficient since guidance and counselling involves not only people offering the service but also relevant supportive material like books and other electronic media. This is an indicator that the government and school administration should revisit the implementation and development of these programmes to ensure that all facilities are adequate. These results coincide with Sindabi (1999), who also in his research noted that Kenyan counsellors lacked facilities thus leading to difficulty in effective implementation of a counselling programme. According to Ndambuki (1999), an ideal guidance and counselling center should consist of a large room with tables where materials are displayed and films or parent - teacher meetings can be held. It is therefore evident that a guidance and counselling facility should be well equipped for effective and efficient service delivery. A lot is therefore left to be desired in the growth of the guidance and counselling departments in the Institutes of Technology in Nyanza. If effective measures are not taken in time, the departments may be rendered irrelevant and the services they provide end up being unable to match with the increasing need for guidance and counselling among students in these institutions.

\section{Attitude towards Guidance and Counselling}

In order to assess the principal's attitude, a sample of 2 principals were asked to respond to general statements on the role of guidance and counselling in the institutions. Their responses showed that their general attitude towards guidance and counselling was positive.

\section{Students Attitude towards Guidance and Counselling}

In order to assess the student's attitude, a sample of 240 students were asked to respond to general statements on the role of guidance and counselling and table 3 presents the results. 
Table 3: Student Responses on the Role of Guidance and Counselling

\begin{tabular}{|c|c|c|c|c|c|c|c|c|c|c|c|}
\hline \multicolumn{2}{|r|}{ Attitude } & \multicolumn{4}{|c|}{ Positive } & \multicolumn{4}{|c|}{ Negative } & \multirow{2}{*}{\multicolumn{2}{|c|}{ NR }} \\
\hline No. & Statement & \multicolumn{2}{|c|}{ SD } & \multicolumn{2}{|r|}{$\mathrm{D}$} & \multicolumn{2}{|r|}{$\mathrm{A}$} & \multicolumn{2}{|c|}{ SA } & & \\
\hline & & Fr. & $(\%)$ & Fr. & $(\%)$ & Fr. & $(\%)$ & Fr. & $(\%)$ & Fr. & $(\%)$ \\
\hline i) & $\begin{array}{l}\text { Guidance and } \\
\text { counselling services are } \\
\text { only for unruly students }\end{array}$ & 153 & 63.8 & 67 & 27.9 & 8 & 3.3 & 6 & 2.5 & 6 & 2.5 \\
\hline ii) & $\begin{array}{l}\text { It is not necessary since } \\
\text { the students are mature }\end{array}$ & 154 & 64.2 & 69 & 28.8 & 7 & 2.9 & 4 & 1.7 & 6 & 2.5 \\
\hline iii) & $\begin{array}{l}\text { It is not necessary } \\
\text { because college rules and } \\
\text { regulations provide } \\
\text { enough guidance }\end{array}$ & 123 & 51.3 & 105 & 43.8 & 4 & 1.7 & 1 & 0.4 & 7 & 2.9 \\
\hline iv) & $\begin{array}{l}\text { It is for the mentally } \\
\text { challenged and weak }\end{array}$ & 124 & 51.7 & 59 & 24.6 & 34 & 14.2 & 12 & 5.0 & 11 & 4.6 \\
\hline & Average response $(\%)$ & & & & 1.275 & & 525 & & 15 & & .125 \\
\hline Over & all attitude (\%) & & & .025 & & & & & & 3.12 & \\
\hline
\end{tabular}

To determine whether the student' attitude was positive or negative, the following criterion was used. Those respondents who strongly disagreed or just disagreed for all the items above were considered to be having a positive attitude towards guidance and counselling while those who agreed or strongly agreed were considered to be having a negative attitude. The average of the responses was then found out by summing up the respective columns and dividing by the number of rows and finally the overall attitude was found by summing up the average responses. The findings of the study in table 3 show that $89.025 \%$ of the students had a positive attitude towards guidance and counselling, $7.625 \%$ had a negative attitude while $3.125 \%$ did not respond.

Maintenance of a proper and positive attitude towards guidance and counselling is key to quick realization of solutions to problems faced by the counsellor and his or her client. The findings of this research reveal that both the principals (70\%) and students $(89.025 \%)$ had a positive attitude towards the guidance and counselling programme. The principals exhibited an understanding of the role of guidance and counselling to the students but even so opposed $(100 \%)$ the fact that the counsellor should be trained. This may be an indication that the principals may be unwilling to support the teacher counsellor in attending to training relevant to this end. This is the likely reason why 50\% of the principals considered financing of counselling departments as not a priority. According to Gibson and Mitchell (2008), guidance and counselling profession is 
considered a helping profession like medicine or law in which members are specifically trained to perform unique and needed human services. The positive attitude of principals and students though tends to indicate that if efforts towards sensitizing the principals on the importance and need for having a well equipped guidance and counselling office are taken, then definitely the facilities will be well equipped and considered with closer and keener interest. The principals will also appreciate the need for a well trained and thoroughly qualified teacher counsellor. Effective measures should therefore be taken to ensure that the right attitude, especially that of principals, is coupled with the right information for better results to be achieved in the guidance and counselling service delivery in TVET institutions.

\section{CONCLUSIONS}

Guidance and counselling programmes in TVET institutions are very crucial components in the harmonious co-existence of all staff and students. The poor equipping of the guidance and counselling departments have very negative consequences on the wellbeing of students within this institutions. Efforts should be put in place to help alleviate this situation. Although the facilities in the guidance and counselling departments are very poor, the positive attitude of both principals and students is great potential to tap from in enhancing better organized guidance and counselling departments in TVET institutions. The government of Kenya and all relevant stakeholders should harness all necessary resources to improve guidance and counselling service delivery in the education sector and especially the TVET institutions that are the master key to development of the country.

\section{RECOMMENDATIONS}

Following the findings of this research, the following recommendations were made in order to alleviate or reduce the challenges being faced in the guidance and counselling service delivery:

i. All managers of ITs in Nyanza Province need to be sensitized, through seminars and workshops, on the urgent need to give adequate support to guidance and counselling programmes in order to enhance better service delivery.

ii. The government should consider employing full time counsellors in the institutes of technology to allow for constant and fulltime access of the students to the counsellors. This will also allow teachers to concentrate on offering teaching duties as counsellors embark on guidance and counselling service delivery.

iii. There is need for education stakeholders to initiate an in-service course programme for untrained teacher counsellors so as to empower them to be able to become meaningful helpers to students.

\section{REFERENCES}

Gibson R. L, and Mitchell M. (2008). Introduction to Counselling and Guidance. New Jersy: Pearson Education Inc.

Kinara I.N, (2002). Perception of Secondary Schools Students on the Importance of Guidance and Counselling in Kisii Central District. Unpublished Master"s Thesis. Universityof Nairobi, Nairobi, Kenya. 
Masinde M. (2003). Problems Facing Students at Kenya Polytechnic. Unpublished Personal Research. Kenya Polytechnic, Nairobi, Kenya

Migiro N.N (2005). An Investigation into the State of Guidance and Counselling in Secondary Schools. Unpublished PGDE Project, Kenyatta University, Nairobi, Kenya.

Nugent F.A \& Jones K.D, (2005). Introduction to the Profession of Counselling. Upper Saddle River New Jersey: Pearson Education Inc.

Pope M. \& Hu X, (2002). The Evolution of Career Guidance and Counselling in the People's Republic of China. The Career Development Quarterly 50, 226-236.

ROK, (1979). Kenya Government Development Plan 1973-1983. Nairobi: Government Printers

Sindabi A.M, (1992). An Analysis of the Guidance and Counselling Programme in Selected Secondary Schools Virginia. Unpublished Doctoral Thesis, Virginia Polytechnic Institute and State University. 